\title{
The Little India riot: experience of an emergency department in Singapore
}

Wei Feng $\underline{\text { Lee }}^{1}$, MBBs, MCEM, Chee Kheong $\underline{\mathrm{Ooi}}^{1}$, MBBS, FCEM, Dong Haur $\underline{\text { Phua }}^{1}$, MBBS, FCEM, Ming Hai Eric Wong ${ }^{1}$, MBBS, FCEM, Wui Ling $\underline{C h a n}^{1}$, MBBS, FCEM, Yih Yng ${\underline{\mathrm{Ng}^{2}}}^{\text {, MBBS, MPH/MBA }}$

INTRODUCTION Singapore experienced its second riot in 40 years on 8 December 2013, in the area known as Little India. A retrospective review of 36 casualties treated at the emergency department was conducted to evaluate injury patterns. METHODS Characteristics including the rate of arrival, injury severity, type and location, and disposition of the casualties were analysed.

RESULTS The injuries were predominantly mild (97.2\%), with the most common injuries involving the head (50.0\%) and limbs (38.9\%). $97.2 \%$ of the casualties were managed as outpatient cases.

CONCLUSION The majority of the injuries in this incident were mild and could be managed as outpatient cases. Important lessons were learnt from the incident about the utilisation of manpower and safety of staff in the emergency department.

Keywords: injury pattern, mass casualty, riot

\section{INTRODUCTION}

Singapore experienced riots on two occasions since its independence in 1965; the first was the racial riots of 1969 and the second occurred on 8 December 2013. The 1969 race riots resulted in four dead and 80 wounded. ${ }^{(1)}$ Civil unrest can result in injuries that pose a challenge to emergency medical services. ${ }^{(2-5)}$ This article describes the emergency medical aspect of the 2013 riot, also known as the Little India riot. It provides a description of the casualties that arrived at Tan Tock Seng Hospital, Singapore, how the designated emergency department (ED) responded to the event and lessons that were learnt from the incident.

On the night of 8 December 2013, at the junction of Race Course Road and Hampshire Road in Little India, Singapore, a fatal accident involving a bus and a pedestrian occurred shortly after 2100 hours. The Singapore Police Force (SPF) and Singapore Civil Defence Force (SCDF) were dispatched to the scene. As the paramedics attempted to extricate the body, an estimated number of over 100 passersby turned into an angry mob and started attacking the police and paramedics. The crowd became more agitated and the numbers grew quickly to about 400 . The Special Operations Command (SOC) was activated to deal with the situation. The rioters pelted the emergency vehicles and the uniformed personnel with projectiles consisting of beer bottles, cans and concrete drain covers that were broken into pieces. With fuel siphoned from nearby vehicles, they set fire to emergency vehicles and also fashioned Molotov cocktails. Out of the six ambulances deployed to the scene, one was completely burnt and two others were badly damaged. Police and SOC reinforcements progressively arrived to control the situation. Witnesses reported that some of the rioters at the scene were intoxicated with alcohol. The situation was brought under control by the early hours of 9 December 2013. Evacuation of casualties to the nearest hospital posed a challenge as the rioters blocked the access routes to and from the scene. The event was not formally declared as a mass casualty incident $(\mathrm{MCl})$ and we postulate that this was due to the sporadic number of cases presenting to hospitals.

\section{METHODS}

A retrospective case review was performed on the patients who were involved in the $\mathrm{MCl}$ and presented to the ED of Tan Tock Seng Hospital. Casualties who presented to the ED were classified according to their patient acuity category (PAC), as PAC1, PAC2 or PAC3. This system is used in all public hospital EDs in Singapore for better resource allocation. PAC1s are patients who are in cardiovascular collapse or imminent danger of collapse and require immediate attention. PAC2s are ill, have severe symptoms and are non-ambulatory. PAC3s are ambulatory patients with mild to moderate symptoms. The following clinical information was collected: (a) age; (b) gender; (c) ethnicity; (d) type of personnel; (e) PAC; (f) injury type; (g) body part affected; and (h) disposition. Data regarding the rate of casualty arrivals to the ED was also collected.

\section{RESULTS}

A total of 36 patients were treated at the ED of Tan Tock Seng Hospital as a result of this incident. 18 patients (50.0\%) arrived within a span of two hours, between 2200 hours and 0000 hours (Fig. 1). The last patient arrived at about 1500 hours the following day. The patients were predominantly middle-aged and consisted mainly of male police and SCDF officers (Table I).

The majority were low-acuity cases, with the exception of one patient with smoke inhalation who was assigned PAC1 status. The most common diagnoses were abrasions, lacerations and contusions. One patient was treated for smoke inhalation and another patient was diagnosed with a closed metacarpal fracture of the right middle finger. The patient diagnosed with smoke inhalation had his arterial blood gas and serum carboxyhaemoglobin levels checked and they were normal. He 


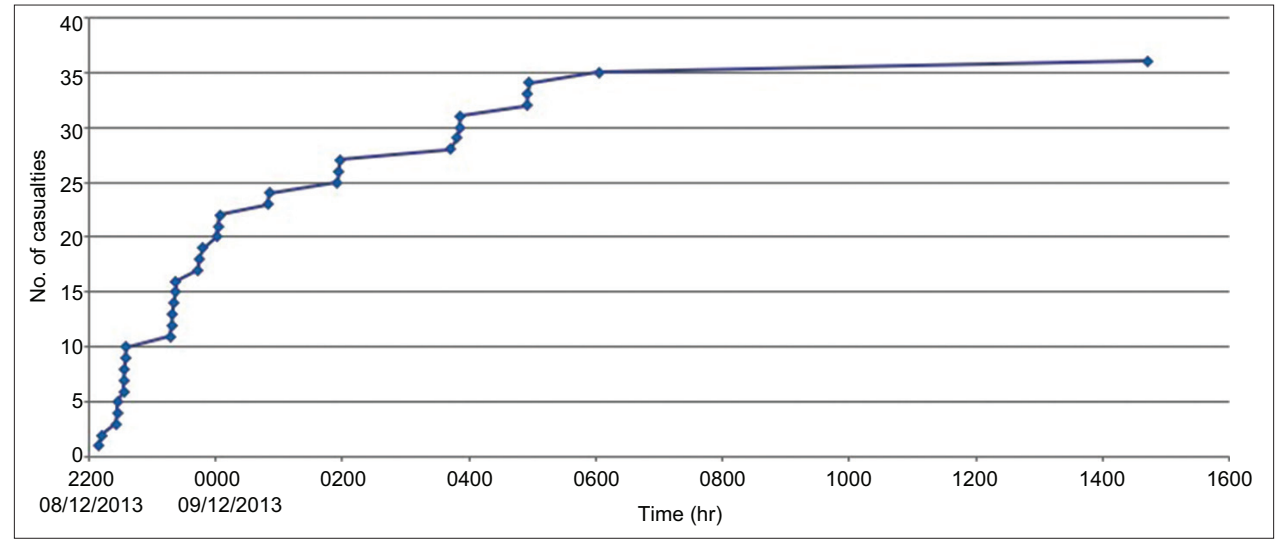

Fig. 1 Graph shows the rate of arrival of patients at the emergency department as a result of the Little India incident.

Table I. Clinical characteristics of patients from the mass casualty incident $(n=36)$.

\begin{tabular}{lc}
\hline Characteristic & No. (\%) \\
\hline Mean age (yr) & 28 \\
Gender & \\
Male & $31(86.1)$ \\
Female & $5(13.9)$ \\
Ethnicity & \\
Chinese & $13(36.1)$ \\
Malay & $15(41.7)$ \\
Indian & $7(19.4)$ \\
Others & $1(2.8)$ \\
Type of personnel & \\
Civilian & $8(22.2)$ \\
Police officer & $18(50.0)$ \\
SCDF officer & $10(27.8)$ \\
Patient acuity category (PAC) & \\
PAC1 & $1(2.8)$ \\
PAC2 & $3(8.3)$ \\
PAC3 & $32(88.9)$ \\
Injury type & \\
Abrasion & $13(36.1)$ \\
Contusion & $13(36.1)$ \\
Laceration & $8(22.2)$ \\
Others* & $2(5.6)$ \\
Body part affected & \\
Head & $18(50.0)$ \\
Trunk & $2(5.6)$ \\
Limb & $14(38.9)$ \\
Others & $2(5.6)$ \\
Disposition & \\
Admitted & $1(2.8)$ \\
Treated and discharged & $35(97.2)$ \\
\hline & \\
\hline & \\
\hline
\end{tabular}

*One patient was treated for smoke inhalation and one patient was diagnosed with a closed metacarpal fracture of the right middle finger. SCDF: Singapore Civil Defence Force

was treated symptomatically and discharged after observation in the ED. All the casualties were treated in the ED and were discharged with outpatient follow-up except one patient who was admitted for the management of a head injury.

\section{DISCUSSION}

A literature review provided little information on injury patterns during riots. A PubMed search was conducted (Table II) and four
Table II. Literature search for Medical Subject Headings (MeSH) terms using PubMed.

\begin{tabular}{llc}
\hline No. & Search query & No. of items found \\
\hline 1 & Riot[MeSH terms] & 325 \\
2 & Civil disorder[MeSH terms] & 1,005 \\
3 & "Wounds and injuries"[MeSH terms] & 688,974 \\
4 & $\# 1$ AND \#2 & 325 \\
5 & Injury & $1,012,051$ \\
6 & $\# 3$ AND \#5 & 688,974 \\
7 & $\# 1$ AND \#6 & 45 \\
8 & \#4 AND \#5 & 46 \\
\hline
\end{tabular}

relevant studies were identified (Table III). The studies showed that the majority of the injuries in civil riots involved the head $(12.6 \%-40.7 \%)$ and limbs $(33.1 \%-81.9 \%) .{ }^{(2-5)}$ This is similar to our study, in which most of the injuries were to the head (50.0\%) and limbs (38.9\%).

Previous reports noted that the severity of injuries among the casualties was predominantly mild (68.5\%-99.1\%). ${ }^{(4,5)}$ The two studies defined mild as having stable vital signs. This is similar to PAC3 in our classification. In our study, only one patient required inpatient care, while $97.2 \%$ of all casualties were managed as outpatient cases. This is similar to other studies, whereby most casualties could be managed as outpatients $(55.9 \%-67.2 \%){ }^{(2,4)}$ The patient who was admitted underwent computed tomography of the head, which did not show any intracranial bleeding. He was observed in the ED short stay unit and subsequently discharged.

Some important lessons were learnt from our experience with the $\mathrm{MCl}$. Firstly, critical information may not come from official channels. The decision to declare civil emergency is made by the Ministry of Home Affairs after a trigger event has been identified and the security risk assessed. The SPF and SCDF are mobilised as necessary, to secure the site and provide medical care. In the event that the incident is declared a civil emergency, the Ministry of Health will proceed to activate EDs at hospitals, requesting them to deploy medical teams to the incident site to provide medical aid and/or to prepare the ED and hospital to receive a surge of casualties. The hospital administrators, together with the head of the ED, will decide if there is a need to activate the mass casualty 
Table III. Relevant studies found in literature review.

\begin{tabular}{|c|c|c|c|c|c|c|}
\hline Year & Incident & Author & Title & No. of casualties & Type of injury & Disposition \\
\hline $1971^{(2)}$ & $\begin{array}{l}\text { Intermittent rioting } \\
\text { with casualties from } \\
1 \text { August-31 October } \\
1969\end{array}$ & $\begin{array}{l}\text { Robb JD, } \\
\text { Matthews JG }\end{array}$ & $\begin{array}{l}\text { The injuries and } \\
\text { management of riot } \\
\text { casualties admitted } \\
\text { to the Belfast hospital } \\
\text { wards, August to } \\
\text { October, } 1969\end{array}$ & 500 & $\begin{array}{l}\text { Head injuries } 12.6 \% \text {, } \\
\text { face and neck } 22.3 \% \text {, } \\
\text { and extremities } 38.2 \% \\
\text { of total injuries }\end{array}$ & $\begin{array}{l}32.8 \% \text { admitted, } \\
\text { with } 56.1 \% \text { of } \\
\text { admitted discharged } \\
\text { within } 1 \text { wk and } \\
34.1 \% \text { discharged } \\
\text { in less than } 48 \mathrm{hr}\end{array}$ \\
\hline $1993^{(4)}$ & $\begin{array}{l}\text { Communal riots } \\
\text { in Bombay with } \\
\text { widespread violence }\end{array}$ & $\begin{array}{l}\text { Dalvie SS, } \\
\text { Pai PR, } \\
\text { Shenoy SG, } \\
\text { Bapat RD }\end{array}$ & $\begin{array}{l}\text { Analytical data of January } \\
1993 \text { communal riot } \\
\text { victims--the KEM Hospital } \\
\text { experience }\end{array}$ & 440 & $\begin{array}{l}\text { Head }(21.7 \%) \text { and } \\
\text { limb }(33.1 \%) \text { injuries } \\
\text { formed the majority of } \\
\text { injuries }\end{array}$ & $\begin{array}{l}6.1 \% \text { were dead } \\
\text { on arrival, } 44.1 \% \\
\text { casualties required } \\
\text { admission and } \\
18.1 \% \text { of those } \\
\text { admitted died after } \\
\text { admission }\end{array}$ \\
\hline $2008^{(5)}$ & $\begin{array}{l}\text { Israeli security forces } \\
\text { and settlers involved in } \\
\text { the forced evacuation } \\
\text { of the Amona outpost }\end{array}$ & $\begin{array}{l}\text { Schwartz D, } \\
\text { Bar-Dayan Y }\end{array}$ & $\begin{array}{l}\text { Injury patterns in clashes } \\
\text { between citizens and } \\
\text { security forces during } \\
\text { forced evacuation }\end{array}$ & 229 & $\begin{array}{l}\text { Head injuries ( } 40.7 \%) \\
\text { and injuries of the } \\
\text { extremities ( } 38.7 \% \text { ) } \\
\text { were the two most } \\
\text { common injury sites }\end{array}$ & $\begin{array}{l}\text { Disposition status } \\
\text { not analysed }\end{array}$ \\
\hline
\end{tabular}

protocol. Unfortunately, due to the unprecedented nature of this event, firsthand information was conveyed informally during this incident from the paramedics who brought casualties to the ED. Media monitoring using mainstream news channels and social media networks, such as Twitter, may be able to provide early warning signs of impending MCls. ${ }^{(6)}$ For example, YouTube was used to evaluate clinical data and management protocols in the Ghouta chemical attack in Syria on 21 August 2013, suggesting that information from unofficial sources can be used to better prepare for future possible events. ${ }^{(7)}$ Although information from such sources may not be trustworthy, emergency physicians should be open to such information so that they can anticipate the type and nature of possible $\mathrm{MCls}$ and plan their responses accordingly.

Secondly, the safety of the staff and ED take priority. The first two casualties who arrived at the hospital were fully armed security force personnel who appeared emotionally traumatised. The nearest police post was activated to disarm them. There was no security screening system that could detect weapons among the riot casualties. This is an important issue to consider, especially during preparation to receive casualties, as the safety of the staff and general public is of utmost importance.

Thirdly, while the ED staff must be familiar with the hospital's $\mathrm{MCl}$ plan, they must also remain flexible, adapting according to the nature of the incident. In the case of the Little India riot, preparation to receive casualties only started when the first two casualties arrived. The emergency physicians on duty discussed the incident with the head of department, who decided not to activate the hospital-wide $\mathrm{MCl}$ plan. However, based on the initial estimated number of 30 casualties, we could have activated the $\mathrm{MCl}$ plan. This would have resulted in the deployment of inpatient staff to augment manpower in the ED. ED staff would also have been recalled to help cope with the expected surge in patient load. For this incident, the decision was made to confine the mobilisation of space and manpower to the ED, as the acuity of the casualties was deemed to be low. The ED has also experienced a few low-acuity MCls in the past (e.g. gastroenteritis outbreaks and accidents involving trucks or buses with multiple casualties) and could cope with the increased volume.

Lastly, the hospital's MCI plan must include a critical incident stress management plan for staff. Handling an $\mathrm{MCl}$, on top of the already hectic and busy environment of the $\mathrm{ED}$, is a highly stressful task. Debriefing after the event is important to ensure that the well-being of affected staff members is assessed and monitored. For this incident, the mental well-being of the ED staff was largely unaffected, as they had previously managed incidents of a similar scale and acuity, and coped well with the emotional stress.

\section{CONCLUSION}

In our series of mass casualty cases following a civil riot, most of the patients arrived very soon after the event started. The majority of the injuries were to the head and limbs and most were lowacuity cases. Almost all the casualties did not require inpatient management. These experiences are similar to those reported in the literature. ED staff should be aware that when such events occur, official communication may be sparse and unofficial information needs to be sought. Staff safety is an important concern. ED staff should be familiar with the institution's $\mathrm{MCl}$ plan but be ready to modify it depending on actual needs on the ground. 


\section{REFERENCES}

1. Conceicao J. The 13th May 1969 (Kuala Lumpur) Disturbances. In Conceicao J. Singapore and the Many-Headed Monster. Singapore: Horizon Books, 2007: 112-3.

2. Robb JD, Matthews JG. The injuries and management of riot casualties admitted to the Belfast hospital wards, August to October, 1969. Br J Surg $1971 ; 58: 413-9$.

3. James WV. Riot injuries to policemen. An analysis of 808 policemen injured in rioting between 1969 and 1972 in Northern Ireland. Injury 1975; 7:41-3.

4. Dalvie SS, Pai PR, Shenoy SG, Bapat RD. Analytical data of January 1993 communal riot victims--the KEM Hospital experience. J Postgrad Med 1993; 39:5-9.
5. Schwartz D, Bar-Dayan Y. Injury patterns in clashes between citizens and security forces during forced evacuation. Emerg Med J 2008; 25:695-8.

6. Tapia AH, Bajpai K, Jansen J, Yen J, Giles L. Seeking the Trustworthy Tweet: Can Microblogged Data Fit the Information Needs of Disaster Response and Humanitarian Relief Organizations. Proceedings of the 8th International ISCRAM Conference. Available at: http://citeseerx.ist. psu.edu/viewdoc/download?rep=rep1 \&type=pdf\&doi=10.1.1.206.5192. Accessed 2 May 2014

7. Rosman $\mathrm{Y}$, Eisenkraft A, Milk N, et al. Lessons learned from the Syrian sarin attack: evaluation of a clinical syndrome through social media. Ann Intern Med 2014; 160:644-8. 